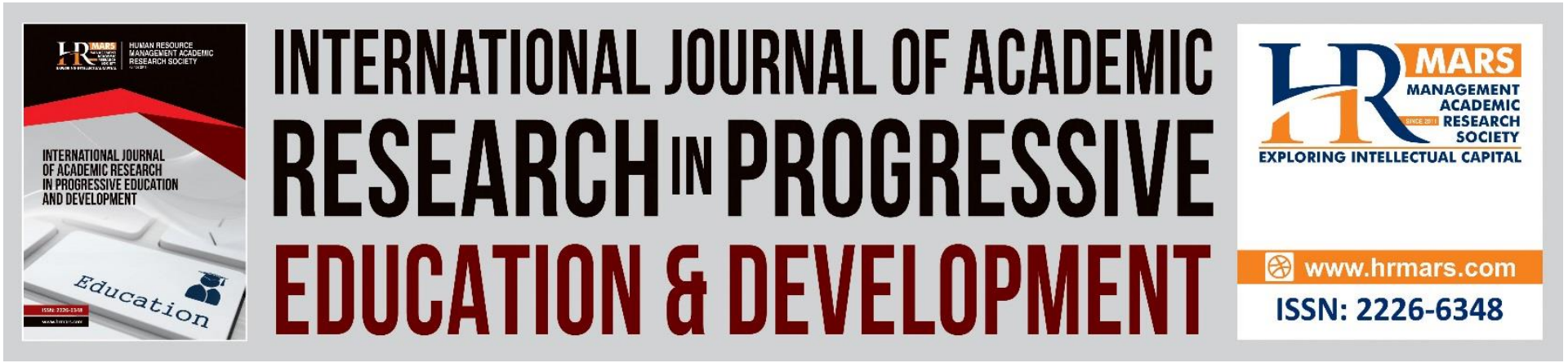

\title{
Sections of Hadith According to Imam Ahmad Al-Daoudi
}

Mwadah Ibrahim Alfaadhli, Mohamed Fathy Mohamed Abdelgelil, Ahmad Fauzi Hassan, Reda Owis Hassan Serour, Mohd Faiz Hakimi Bin Mat Idris

To Link this Article: http://dx.doi.org/10.6007/IJARPED/v10-i3/11187 DOI:10.6007/IJARPED/v10-i3/11187

Received: 17 July 2021, Revised: 20 August 2021, Accepted: 04 September 2021

Published Online: 22 September 2021

In-Text Citation: (Alfaadhli et al., 2021)

To Cite this Article: Alfaadhli, M. I., Abdelgelil, M. F. M., Ahmad Fauzi Hassan, R. O. H. S., \& Idris, M. F. H. B. M. (2021). Sections of Hadith According to Imam Ahmad Al-Daoudi. International Journal of Academic Research in Progressive Education and Development, 10(3), 766-774.

\section{Copyright: (C) 2021 The Author(s)}

Published by Human Resource Management Academic Research Society (www.hrmars.com)

This article is published under the Creative Commons Attribution (CC BY 4.0) license. Anyone may reproduce, distribute, translate and create derivative works of this article (for both commercial and non-commercial purposes), subject to full attribution to the original publication and authors. The full terms of this license may be seen at: http://creativecommons.org/licences/by/4.0/legalcode

\section{Vol. 10(3) 2021, Pg. 766 - 774}




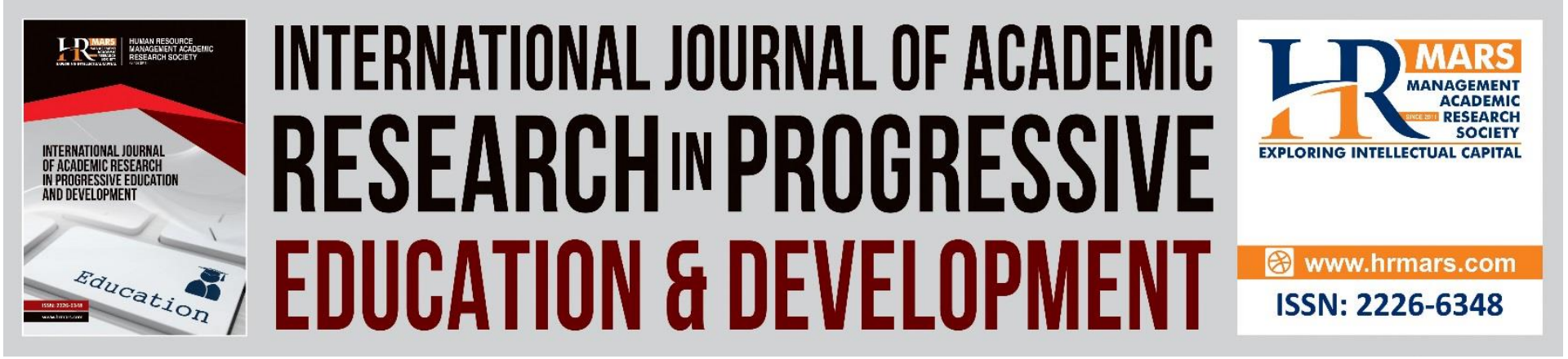

\title{
Sections of Hadith According to Imam Ahmad Al- Daoudi
}

\author{
${ }^{1}$ Mwadah Ibrahim Alfaadhli, ${ }^{1}$ Mohamed Fathy Mohamed \\ Abdelgelil, ${ }^{1}$ Ahmad Fauzi Hassan, ${ }^{2}$ Reda Owis Hassan Serour, \\ ${ }^{1}$ Mohd Faiz Hakimi Bin Mat Idris \\ ${ }^{1}$ Faculty of Islamic Contemporary Studies (FKI), Sultan Zainal Abidin University (UniSZA), \\ 21300, Terengganu, MALAYSIA, ${ }^{2}$ Sultan Abdul Halim Mu'adzam Shah International Islamic \\ University, (UniSHAMS), Malaysia. \\ Email: mfathy@unisza.edu.my
}

\begin{abstract}
Tripoli, west of Libya, embraced many imams of hadith, including Imam Ahmed bin Nasr AlDaoudi. He was born in Algeria and then moved to Tripoli in the West, where he settled and spread knowledge, during the days of the state of the plight of Bani Ubaid in Almaghrib, it was the cause of the deterioration of political, social and scientific life. Where their history was famous for injustice, insulting the alsahabah and killing alaulamah, until innovations and abominations appeared in their state, and the people of corruption increased and the righteous among them were few among the alaulamah and aubbad, and the one who is interested in the science of hadith must know the efforts of Al-Daoudi hadith, because of his position and progress in this art, and he can only do that after, a lot of trouble. due to the loss of most of his precious books and classifications. The research aims to know Al-Daoudi's efforts in judging the hadiths, and to clarify what is accepted from them and what is received. One of the results of the research is that Al-Daoudi is an imam in criticizing the narrators; He was not just a transmitter of the rulings of others, but he had a prominent effect in correcting hadiths, criticism, and clarification of the ills. So he used several words in jarh and ta'deel, and heopted some of the words that indicate acceptance, such as his saying: "proven" or "confirmed" and his saying: "It is not correct." In its chain of narrators, there is an examination of the hadith in which there is a defect. And his saying: In the hadith is a maqal, for the chain of narrators that the alaulamah differed in documenting one of its men, al-Dawudi confined himself to the least that would achieve the purpose and does not go beyond that to what is above it.
\end{abstract}

\section{Introduction}

Praise be to Allah, Lord of the Worlds, and the outcome for the righteous, and prayers and peace be upon our master Muhammad peace be upon him and his family and companions, and may peace and blessings be upon the Day of Judgment.

With the passage of days and the succession of times, illusion and error occurred in the narration; And even the lie appeared on the chosen prophet peace be upon him. At that time, 
Allah sent a group of memorized imams, they worked hard in collecting antiquities, and the fourth century $\mathrm{AH}$ did not end until their works absorbed the hadiths of the Messenger of Allah peace be upon him, and the traces of his companions, as well as the books of al-Jarh and al-Ta'deel and an explanation of the conditions of narrators, to distinguish the correct from the weak and the sound from the cause, and the imams took several approaches to reach What they wanted, knowing the approach of the forerunners was inevitable, because the people of knowledge are not on the same approach in the alhadithia industry; Rather, it is based on multiple approaches, so it is necessary to know their method and then follow it. Imam Ahmad Al-Daoudi was one of these imams; He is one of those who took care of him, so they distinguished between the true and the weak hadith. Al-Dawudi was one of the people of experience and insight. His writings included a lot of modern valuables, and his sayings were transmitted by many modern imams.

And when Daoudi's efforts in serving the Sunnah were of such great importance, it was worth directing the efforts of scholars and researchers to him, translating his life, and extracting his ideas, opinions and judgments.

\section{Background}

In order to know the topic around which the research revolves, a brief explanation of the introduction to Imam Ahmed Al-Daoudi and the study of his era must be provided, Imam Daoudi lived during the era of the state of Bani Ubaid, which was established in the year 297 $\mathrm{AH}$ in the Arab Maghreb, and its founder is Ubaid, who entered the Maghreb and was called Ubaid Allah, and he was a Jew. Al-Qadi Ayyad told that the Sunnis in Kairouan were in the days of Bani Ubayd, in a severe state of oppression and cover-up, as if they were a dhimma, which overwhelmed them in many days of severe ordeals (Ayad, 5:303). Naji said: Their era in Tripoli was one of chaos and calamities (Naji, 1970, p. 136).

\section{Introduction to Imam Ahmed Daoudi}

$\mathrm{He}$ is Ahmed bin Nasr Al-Daoudi, Al-Asadi, Al-Musili by birth, Al-Tarabulsi by birth, Al-Tilmisani by death. (Ayad, 1982, 7: 102-104; Al-Zawi, 2004, p. 92).

Imam Daoudi left his hometown of Msila to Tripoli, and his first life was in Tripoli, the West, where he resided and sought knowledge in it, and with it he dictated his developing book in Sharh Al-Muwatta. Indition to seeking knowledge, he settled in Tripoli fleeing the strife of Bani Ubaid, and after Imam Daoudi resided in Tripoli for a period of time seeking knowledge, he moved to Tlemcen and settled there until his death in $402 \mathrm{AH}$ (Ayad, 1982, 7: 102-104, and Al-Zawi, 2004, p. 92).

\section{Sections of Hadith According to Imam Daoudi}

Al-Daoudi, like other hadith scholars, sees dividing the hadith relatively into several divisions in terms of general and specific, and in terms of the multiplicity of paths, and in consideration of acceptance. Examples of this are the following:

\section{His Releases of the Word Hadith, Impact and ALkabar}

Ibn Hajar defined the ALkabar by saying: "The news: for scholars of this art is synonymous with hadith" (Ibn Hajar, 2008, p. 35). Ibn Jama'ah said in al-Manhal al-Rawi: "Some of the jurists call the suspended one athar and the one with the report, while the people of hadith call the athar on both of them" (Ibn Jama'ah, 1406 AH, p. 
Al-Sakhawi said: "But the modernists - as Al-Nawawi attributed to them in his two books refer to the traceable and the suspended" (Al-Sakhawi, 2003, 1: 137). And Imam al-Dawudi has hadith and narration with one meaning, but he contrasts between Alathar and Alkabar, such as his saying: "It is as if the Alkabar was not proven to them, and this is only in the sense of reconciliation, not in the sense of zakat" (Al-Daoudi, 2008, p. 135).

In the hadith narrated by Al-Bukhari in the Book of Expression, Chapter, The Vision of the Righteous, with its chain of transmission on the authority of "Anas bin Malik that the Messenger of God peace be upon him said: "A good dream is from a righteous man.").

Al-Daoudi said: In the report there is evidence that the dreams of the prophets are like revelations in their wakefulness. (Ibn Al-Mulqen, 2008, 32: 124). Al-Bukhari said in the Book of Wills: "Anas endowed a house, and when he came to it, he would stay in it" (Bukhari, 1422 $\mathrm{AH}, 4: 13)$. Al-Bukhari commented Al athar here in the form of Jazm. Al-Bayhaqi narrated it in the Book of Endowment, the chapter on alms, with its chain of transmission on the authority of Thumama, on the authority of Anas, that he "donation a house in Madinah." (Al-Bayhaqi, 2003, 6: 267.11901). Ibn Al-Mulqen said: "Al-Daoudi said: The Athar of Anas is authentic" (Ibn Al-Mulqen, 2008, 17:302).

Narrated by Bukhari in the book of Hajj, narrated from Mujahid, said: We were at the Ibn Abbas, may Allah be pleased with them, they cited the Almaseih, he said: written between his eyes infidel, Ibn Abbas said: I did not hear him, but he said: "As for Mosa, as I am now looking at him getting down in the valley and saying Labbaik." (Bukhari, $1422 \mathrm{AH}, 2$ : 139, No. 1555). Ibn Al-Mulqen said: "Al-Daoudi claimed that the saying of those who narrated "Mosa" are among the narrators, because there was no Athar or kabar about Moses that he is alive, and that he will perform Hajj. Another: "May the son of Mariam greet Faj al-Ruha'a" (Ibn alMulqen, 2008, 11: 180). Al-Dawudi's saying in the previous examples: (And in the Reiwayah), and (Athar Anas), and (Neither Athar nor kabar has come) is evidence of their difference in his view.

He has the news and the hadith in one sense, which is the one that was attributed to the Prophet ?, and the Athar is not on the Companion.

\section{Sections of Hadith in terms of Multiplicity of Ways}

By looking at the sayings of Imam Daoudi, it becomes clear that Daoudiheres to the definitions of Akbar methods in terms of its sections: Mutawatir, Almustafid and Al-Ahad, and detailed as follows:

\section{First / Al-Mutawatir}

Al-Daoudi's Mutawatir is what he quoted from Alkaffah of Alkaffah agreeing on a matter; Where he said in the book of Al-Amwal in his answer to one of the questions that he was asked: "The transmission of knowledge in one way, and its transmission by Alkaffah of Alkaffah, is based on what was transmitted from their transmission..." (Al-Daoudi, 2008, p. 86).

Alkaffah: means the group. (Ibn Manzur, $1414 \mathrm{AH}, 9: 305)$.

He said in the hadith of Almghfer:

The hadiths tawatart, and they pretended that Mecca was conquered by force, and that the Prophet entered it lawful and forgiving with his head bowed humble to Allah Almighty. And he says: "The Sovereignty of Allah is the One, the Subduer" (Al-Daoudi, 2008, p. 124). 
DEVELOPMENT

Vol. 10, No. 3, 2021, E-ISSN: 2226-6348 ㄷ 2021 HRMARS

\section{Second / Al mashhur and Al mustafid}

Through the transmission of alaulamah on the Daoudi, we find him mentioned al mashhur in several places, including:

In the hadith that Al-Bukhari included in the Book of Interpretation of the Qur'an, with its chain of transmission on the authority of "Aisha, may Allah be pleased with her, she said: "A necklace belonging to Asma' was lost, and the Prophet may Allah bless him and grant him peace, sent men in its search " (Bukhari, $1422 \mathrm{AH}, 6: 46)$.

Al-Daoudi said: The hadeeth "A necklace belonging to Asma' was lost, and the Prophet may Allah bless him and grant him peace, sent men in its search " (meaning: ayat alttayammum). And in another hadith: "She borrowed a necklace from Asma, but it fell apart, so he sent men to ask for it, and they prayed without ablution." Al-Bukhari included it in the Book of Dress, in the chapter on borrowing necklaces, with its chain of transmission on the authority of Hisham, on the authority of his father, on the authority of Aisha, may Allah be pleased with her. (Bukhari, $1422 \mathrm{AH}, 7:$ 158, No. 5882).

Then Al-Daoudi said: It is possible that this hadith clarifies the rest of the hadiths. Because heded the contract to Aisha knowing that it was forfeited for her, thinking that she owns it. (Ibn Al-Mulqen, 2008, 22: 231). By quoting Al auolamah on the authority of Al-Daoudi, we also find that he mentioned Al mustafid in several places, including:

In the hadeeth narrated by Bukhari in the book of Alhodoud, the door of the stoning of pregnant woman, narrated from Ibn Abbas, a long interview in which: "while the emigrants gathered with Abu Bakr. I said to Abu Bakr, 'Let's go to these Ansari brothers of ours" (Bukhari, $1422 \mathrm{AH}, 8: 168$, No. 6830).

Ibn Al-Mulqen said: "And his saying: (And the Muhajireen gathered to Abu Bakr) Al-Dawdi said: I do not see this word being proven, because the most Al mustafid narrations were narrated by Malik and others that Abu Bakr and Omar were in the house of Aisha..." (Ibn AlMulqen, 2008: 31. 225).

Then we find Al-Dawudi distinguishes the Al mustafid one by means of many ways. He said about Alamwal: and in the Al mustafid narrations from the many paths, that Umar kept the blackness of Iraq and Egypt and what appeared to him from the Levant to be in the fighting gifts, and the livelihood of Al-Hashwa and Al-Darari, and that Al-Zubayr, Bilal and other than one of the Companions wanted him according to the division of what opened to them the idea of that from them" (Al-Dawudi, 2008, p. 45).

This study shows that Daoudiheres to the definitions for the ways of Alkabar in terms of its sections, here he mentioned Alkabar of the Al-Ahad, which came from many paths, but it did not reach the level of Mutawatir.

\section{Third / Al-Ahad}

Al-Bukhari included in the Book of Al-eatesam, with his chain of transmission on the authority of Abu Al-Minhal, he told him that he had heard Abu Barzah, said: "O people, Allah makes you self-sufficient or has raised you high with Islam and with Muhammed" (Bukhari, $1422 \mathrm{AH}, 9$ : 91, No. 7271).

Ibn Al-Mulqen said: "Al-Daoudi said: His mention of the hadith of Abu Barzah was only to accept kabar of the one" (Ibn Al-Mulqen, 2008, 33: 11). 
DEVELOPMENT

Vol. 10, No. 3, 2021, E-ISSN: 2226-6348 ㄷ 2021 HRMARS

\section{Sections of Hadith Regarding Acceptance}

From the approach of Imam al-Dawudi, he uses the word: It is proven, or fixed, and good, for the accepted hadith, it was presented to the most reliable and sounder than others, including the following:

\section{First / His saying: (proven, or fixed)}

Al-Daoudi said: "And it is proven that the Prophet, may Allah bless him and grant him peace, said: "Seven are loyal to them, they have no guardian except Allah and His Apostle, The tribe of Quraysh, the Ansar, Julhaina, Muzaina, Aslam, Ashja', and Ghafar". (Al-Daoudi, 2008, p. 126).

Al-Bukhari included it in the Book of Almanaqeb, Chapter on the Almanaqeb of Quraysh, with its chain of transmission on the authority of Abu Hurairah, may Allah be pleased with him, similar to it. (Bukhari, $1422 \mathrm{AH}, 4: 179$, No. 3504).

1-Translated by Bukhari in the Book of Zakat, he said: "the chapter of no combining sporadic, does not differentiate between the community, and reminds Salem, Ibn Umar, the Prophet peace be upon him like him" (Bukhari, 1422, 2: 116).

Ibn al-Mulqen said: "The almuealiq was first attributed by al-Tirmidhim, benefactor to him. He said: and so are the general aleulamah. He said in his "ealalihi":

I asked Muhammad about the hadith of Salem, on the authority of his father: The Prophet of Allah, may Allah bless him and grant him peace, wrote the Book of charity and said: I hope it is preserved, and Sufyan bin Hussein is honest. Daoudi said: it is a fixed hadith" (Ibn al-Mulqen, 2008, 10: 375).

\section{Secondly/ saying: (Good)}

Al-Daoudi said: "It was narrated on the authority of the Prophet may Allah bless him and grant him peace, with a good chain of narrators, that he said: "Charity is not permissible for the rich person, or for one who are strong and healthy." And this time: the right, perverted, or: the person of work who has received a pension for that and strength to live" (Al-Daoudi, 2008, p. 154).

The hadith was included by Abu Dawood in the Book of Zakat, chapter on who is given from charity, and Ahmad in his Musnad, on the authority of Saad bin Ibrahim, on the authority of Rayhan bin Yazid Al-Amri, on the authority of Abdullah bin Amr - may Allah be pleased with them both (Abu Dawudi, 2009, 3: 76, No. 1634; Ibn Hanbal, 1995, 6: 94, No. 6530).

Sheikh Ahmad Shakir said in his commentary on the Musnad of Ahmad, "Its chain of narrators is authentic, Rayhan bin Yazid Al-Amiri: tabiei trust. Ibn Muin and Saad bin Ibrahim trusted him." Then he said: "Some aleulama have emphasized this hadith with reasons that are not based on criticism." Then he mentioned it in detail and extended the hadith in it, and followed it up by saying: "So this hadith is a saheeh hadeeth, whether it is marfoo' or mawqoof, and it has no fault, and everyone emphasized has been mistaken" (Ibn Hanbal, 1995, 6: 94-99).

\section{Thirdly, submitting it to the narration that is more reliable and more correct than others $\backslash$}

Al-Bukhari said in the Book of Jihad and Alssiar: "Ibn Namir said, Abidu Allah told us, from Nafaa from Ibn 'Umar, may Allah be pleased with them, he said, horse of Ibn 'Umar fled and the enemy took it. Then the Muslims conquered the enemy and the horse was returned to him during the lifetime of Allah's Messenger may Allah bless him and grant him peace. And also, once a slave of Ibn 'Umar fled and joined the Byzantines, and when the Muslims 
conquered them, Khalid bin Al-Walid returned the slave to him after the death of the Prophet may Allah bless him and grant him peace (Bukhari, 1422 AH, 4: 73, No. 3067).

Then Al-Bukhari narrated "Musa bin Aukbah from Nafaa from Ibn Umar may Allah be pleased with them both: "That he was riding a horse on the day, the Muslims fought (against the Byzantines), and the commander of the Muslim army was Khalid bin Al-Walid who had been appointed by Abu Bakr. The enemy took the horse away, and when the enemy was defeated, Khalid returned the horse to him". (Bukhari , 1422 AH, 4: 73, No. 3069).

Ibn al-Mulqen said when explaining this chapter: "And Ibn Umar's horse is in this commentary (i.e.: Ubaid Allah's first hadith). It was replied at the time of the Prophet of Allah may Allah bless him and grant him peace, and in the last, the Musnad (i.e.: the second hadith of Moses) that Khalid rejected it, and the first Daoudi corrected it, and that he was in the battle of Mu'tah, he said: "And Ubaid Allah is more steadfast in Nafaa than Moses" (Ibn Al-Mulqen, 2008, 18: 317).

\section{Conclusion}

At the end of this research, the most important findings can be shown as follows:

- Al-Dawudi, like other hadith scholars, sees dividing the hadith relatively into several divisions in terms of generality and specificity, and in terms of multiple paths, and considering acceptance. He also sees that the kabar and the hadith have the same meaning, which is attributed to the Noble Prophet may Allah bless him and grant him peace, and that the effect is different from them, which is what stood on the companion.

- Al-Dawudiheres to the definitions of the narrators of the news in terms of its Mutawatir, Almustafid and Alahad. And he sees by accepting the news of the one, and that the Daoudi approach uses the word: proven, or fixed, and good, for the accepted hadith, and presenting it to the most reliable and sounder than others, referring to the conditions of some narrators.

\section{References}

Al-Quran Al-Karim.

Abdelgelil, M. F. M. (2020). Grammarians' Critique of Qur'anic Qira'at. International Journal of Academic Research in Business and Social Sciences, 10(11), 1225-1231.

Abdelgelil, M. F. M. (2020). Solving the Quranic Issues with Quranic Qira'at, International Journal of Academic Research in Business and Social Sciences, 10(12), 36-42.

Abdelgelil, M. F. M., Al-Janayni, M. U., Baru, R., Hamzah, M. S., Razali, M. A. T. M., \& Ismail, F. Z. (2018). Tawjih Al-Qira'at Based on Inscription, Language, and Unusual Modes of Recitation According to Ibn Zanjalah. International Journal of Academic Research in Business and Social Sciences, 8(10), 362-370.

Abdelgelil, M. F. M., Daud, N. B., Omar, N. B., Ismail, F. Z. B., \& Wahab, A. H. B. A. (2018). Taujeeh Al-Qira'at Using Qur'an, Hadith and Poetry according to Ibn Zanjalah. International Journal of Academic Research in Business and Social Sciences, 8(10), 371-379.

Abdelgelil, M. F. M., Hasan, A. F., Yusoh, F, El khayat, M. H. M., Razali, M. A., Ismail, F. Z., \& Ab Rashid, R. (2021). Correlation Between Irregular Qiraat And Arabic Linguistics In The Quranic Tafseer Book By Al-Razi. International Journal of Academic Research in Business and Social Sciences, 11(7), 1632-1639. 
Abdelgelil, M. F. M., Hasan, A. F., Yusoh, F., Ismail, F. Z., Ab Rashid, R., Ab Aziz, N. S., Hassan, A (2021). The Impact of Irregular Qiraat on Arabic Semantics and Dialects. International Journal of Academic Research in Business and Social Sciences, 11(7), 1672-1676.

Abdelgelil, M. F. M., Hasan. A. F., Yusoh, F., El khayat, M. H. M., Razali, M. A., Hassan, A., Ab Aziz, N. S. (2021). Arabic Syntactic Rules with Reference to Quranic Qurra. International Journal of Academic Research in Business and Social Sciences, 11(7), 1707-1711.

Abdelgelil, M. F. M., Musolin, M. H., Serour, R. O. H., Abdullah, M. S., \& Noor, M. N. M. (2018). Law and Moral Values in the Holy Quran. International Journal of Academic Research in Business and Social Sciences, 8(11), 445-451.

Abdelgelil, M. F. M., Osman, M. F. M. A., Serour, R. O. H., Subagio, M. H. M., Othman, A. K. I., \& Hassan, A. F. (2021). The History of the Qur'anic Enigma and the Impact of Interpretation in Directing it. International Journal of Academic Research in Progressive Education and Development, 10(3), 412-418.

Abdelgelil, M. F. M., Othman, A. K. I., Serour, R. O. H., Osman, M. F. M. A., \& Hassan, A. F. (2021). Ibn Qutayba's Response to the Slanderers who Claim Grammatical Mistake in the Qur'an. International Journal of Academic Research in Progressive Education and Development, 10(3), 419-426.

Abdelgelil, M. F. M., Othman, A. K. I., Subagio, M. H. M., Serour, R. O. H., Hassan, A. F., \& Osman, M. F. M. A. (2021). Directing the Enigma of Quranic Words According to Ibn Qutaybah and Al-Far. International Journal of Academic Research in Progressive Education and Development, 10(3), 427-434.

Abdelgelil. M.F.M, Hassan. A, Yusof. N.H, Idris. M.F.H, Hasan. A.F and Ramadan. A.A. (2020). Defending the Quran in the Study of Tawjeeh Al-Qira'at, International Journal of Management, 11(10), pp. 101-104.

Abdelgelil. M.F.M, Razali. M.A, Hassan. A, Hasan. A.F, Idris. M.F.H and Masoud. (2020). A.S,Quranic Inimitability in Quranic Qiraat, International Journal of Management, 11(10), pp. 117-121.

Abu Dawud, S. (2009). Sunan Abi Dawood. Investigated by: Shuaib Al-Arnaout, and Muhammad Kamel Qara Belli. Global Message House.

Al-Bayhaqi, A. (2003). Alsunan Alkubraa. Investigation: Muhammad Abdul Qadir Atta. Beirut: Scientific Books House.

Al-Bukhari, M. (1422 AH). Sahih Bukhari. Investigation: Muhammad Zuhair Al-Nasser. Cairo: Lifeline House.

Al-Sakhawi, M. (2003). fath almughith bisharh 'alfiat alhadith of the Iraq. Investigation: Ali Hussein. Cairo: Alsunan Library.

Al-Zawi, A. (2004). Aalam Libya. Beirut: Dar al-Madar al-Islami, Tripoli: Dar Oya.

Daoudi, A. (2008). Kitab Al'amwal. Investigation: Reda Muhammad Salem Shehadeh. Beirut: Scientific Books House.

Ebin Jamaah, M. (1406 AH). Al-Manhal Roy in the summary of modern sciences. Investigation: Mohieddin Abdul Rahman Ramadan. Damascus: Dar Al-Fikr.

Ibn al-Mulqen, S. (2008). clarification to explain the Aljamie Alssahih. Investigation: Beirut: Dar Al-Falah. Damascus: Dar Al-Nawader.

Ibn Hajar, A. (2008). Excursion to clarify the elite of thought. Investigation: Abdullah Al-Rahili. 
Ibn Hanbal, A. (1995). The predicate of Imam Ahmad bin Hanbal. Investigation: Ahmed Mohamed Shaker. Cairo: Dar Al-Hadith.

Ibn Manzoor, M. (1414 AH). Lisan Al-Arab. Beirut: Dar Sader.

lyadh, A. (1982). Tartib Almadarik Wataqrib Almasalik. Investigation: Saeed Ahmed Arab. Morocco: Ministry of Endowments and Islamic Affairs.

Iyadh, A. (N. D). Tartib Almadarik Wataqrib Almasalik. Investigation: Muhammad bin Sharifa. Morocco: Ministry of Endowments and Islamic Affairs.

Nagy, M. (1970). History of Tripoli West. Translation: Abdel Salamham. Benghazi: Libyan University Publications. 